\title{
Chaotropic effect of trifluoroacetic and perchloric acid on $\beta$-cyclodextrin inclusion complexation process with risperidone, olanzapine and their selected impurities
}

\section{Nevena Djajić, Jovana Krmar, Andjelija Malenović, Biljana Otašević, Ana Protić*}

\author{
University of Belgrade - Faculty of Pharmacy, Department of Drug Analysis, \\ Vojvode Stepe 450, 11152 Belgrade, Serbia \\ *Corresponding author: Ana Protić, E-mail: anna@pharmacy.bg.ac.rs (A. Protić).
}

\begin{abstract}
Effective method development together with method`s eco-friendly character are gaining importance in drug analyses nowadays. One of the strategies often applied to improve the efficacy of separation methods, especially in the case of basic ionizable analytes is adding chaotropic salts into the mobile phases. Moreover, the development of the green liquid chromatography method could also be achieved with certain mobile phase additives such as cyclodextrin (CD). The study aims to investigate whether adding chaotropic agents could improve the complexation process by disrupting the analytes' water solvation shell. The model mixture consisted of risperidone, olanzapine, and their related impurities. Method development was aided with experimental design methodology, while optimal separation conditions were selected using Derringer's desirability function. Mathematical models obtained for each of the examined responses enabled the explanation of the single and simultaneous influence of $\beta$-CD concentration, chaotropic agents type, and content, as well as the content of acetonitrile in the mobile phase. Retention factors appeared to be the most influenced by acetonitrile content in the mobile phase. The type of chaotropic agent as well as its concentration lead to retention prolongation, but if acetonitrile content in the mobile phase is high, the effect of chaotropic agent becomes negligible. Interaction between analyte and $\beta-\mathrm{CD}$ are relatively weak in comparison to the interaction of analyte form with either chaotropic agent or acetonitrile. Interaction leading to complexation are outperformed by other analyte related interactions in this complicated system, so complexation based retention reduction is not fully exposed. However, increasing $\beta$-CD concentration shows a positive effect on the resolution between critical peak pairs. Optimal separation conditions were selected based on 3D plots of Derringer's desirability function. For olanzapine and its impurity, they included the following: acetonitrile content $16 \%(\mathrm{v} / \mathrm{v})$, trifluoroacetic acid as a chaotropic agent with $0.95 \%$ $(\mathrm{v} / \mathrm{v})$ content, and $9 \mathrm{mM} \beta-\mathrm{CD}$ concentration. Further, optimal separation conditions for risperidone and its impurity were $25 \%(\mathrm{v} / \mathrm{v})$ acetonitrile content in the mobile phase, trifluoroacetic acid as chaotrope agent with $0.27 \%(\mathrm{v} / \mathrm{v})$ content and $5 \mathrm{mM} \beta-\mathrm{CD}$ concentration.
\end{abstract}

Keywords: risperidone; olanzapine; chaotropic agents; $\beta-\mathrm{CD}$;

Derringer's desirability function

DOI: https://doi.org/10.5937/arhfarm70-28865 


\section{Introduction}

Liquid chromatography, usually considered a universal technique, has certain advantages over other chromatographic techniques which made it the most applied one. Its advantages are reflected in high precision and easily available instruments and columns. Knowing the characteristics of most analytes, reversed-phase High Performance Liquid Chromatography (RP-HPLC) is the most frequently used in the drug analysis (1). Keeping up with the advances in HPLC, there is a constant need for improvement of its efficacy on one hand, and its ecological acceptability on the other hand. Therefore, there are different strategies used to modify the present HPLC methods to meet the new standards.

Effective method development in drug analyses leads to an increased investigation of different mobile phase additives and its influence on retention behaviour, especially in the case of ionizable analytes (2). If analytes are basic, mobile phase additives such as ion-pairing reagents are the most frequently used. However, due to certain limitations in their suitability, inorganic salts, called chaotropic salts, took the leading role (3). Chaotropic salts got the name after their activity of order breaking, namely they can disrupt the analyte solvation shell thus strengthening the hydrophobic interactions $(3,4)$. Mobile phases with chaotropic salts could influence the retention of protonated basic analytes in RP-HPLC, in terms of retention prolongation. In the same way, an increase in peak symmetry and efficiency would occur $(3,5)$.

On the other hand, developing a green RP-HPLC method has become an ultimate goal in drug analyses nowadays. Among the available strategies, there are ones including usage of mobile phase additives, such as cyclodextrin (CD). CDs are widely used as mobile phase additives due to their ability to incorporate different organic compounds within the cavity $(6,7)$. Consequently, inclusion complexation leads to changes in physicochemical characteristics of incorporated analytes, reducing its retention (8). Reduction in analyte retention time causes shorter analyses and low organic solvent consumption, which is contributing to eco-friendly postulates (9). In CD-modified RPHPLC systems, the binding process between the host CD cavity and the guest molecule is not permanent, but rather represents a dynamic equilibrium (10). Water molecules surrounding the hydrophobic $\mathrm{CD}$ cavity are inducing the complex formation by the exchange of these enthalpy-rich water molecules from the cavity with hydrophobic guest molecules in the solution (11). There are different ways to relocate the equilibrium in the complex formation direction. Namely, the complex formation can be induced by supplanting the water molecules from the hydrophobic CD cavity followed by forming many hydrogen bonds along with returning the water molecules to the pool. Moreover, the decrease of repulsive forces between aqueous solution and hydrophobic guest molecule as well as the increase in hydrophobic interactions upon insertion of the guest molecule into the CD cavity could lead to host-guest complex formation (10). Having in mind the aforementioned, $\beta$-CD complexation process could be affected with $\mathrm{CD}$ type and cavity size, together with $\mathrm{pH}$ and ionization state of the guest molecule, and other additives present in the mobile phase. Therefore, the study aimed to analyze whether 
added chaotropic agents would affect the complexation process by disrupting the water shell and thus strengthening the interactions leading to complex formation. Among different $\mathrm{CDs}, \beta-\mathrm{CD}$ was used for this study, while risperidone, olanzapine, and their related impurities were selected as model substances (Figure 1).

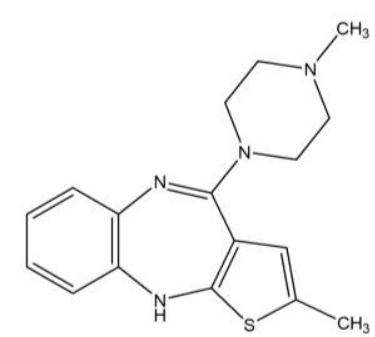

Olanzapine

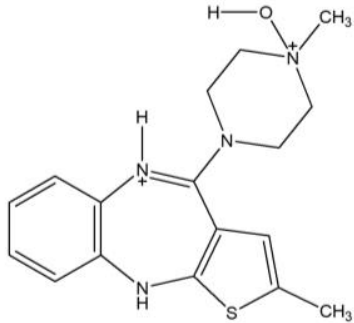

Olanzapine related impurity

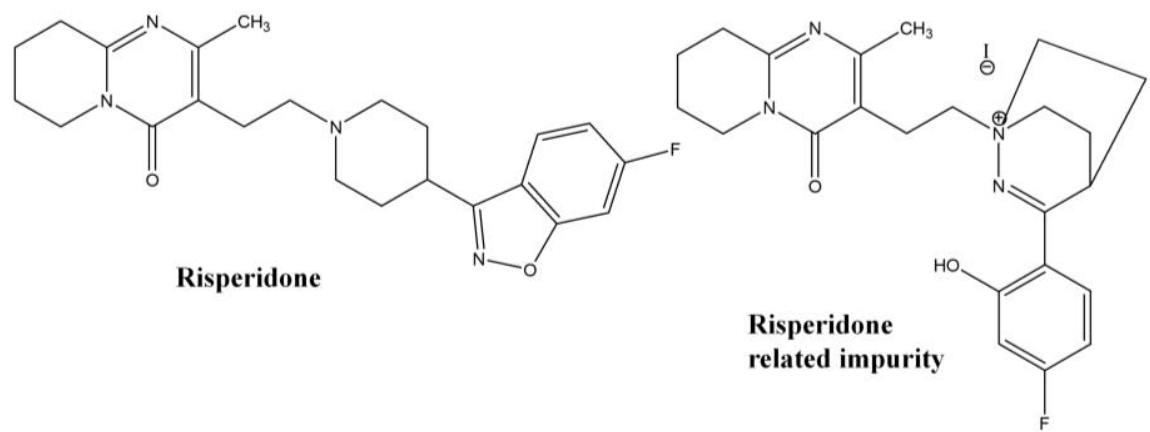

Figure 1. Chemical structures of risperidone and its related impurity, as well as olanzapine and its related impurity

Slika 1. Hemijske strukture risperidona i njegove srodne supstance i olanzapina i njegove srodne supstance

\section{Experimental}

\section{Chemicals and reagents}

Reference standard substances of risperidone and its related impurity were obtained from Jannsen Pharmaceutical N.V. (Beerse, Belgium), while olanzapine and its related impurity reference standard substances were from USP - U.S. (Rockwil, USA). $\beta$-CD was purchased from Sigma Aldrich Chemie GmbH (Taufkirchen, Germany). Perchloric and trifluoroacetic acid, used as chaotropic agents, were obtained from Riedel-de Haën AG (Seelze, Germany). HPLC grade acetonitrile was from Sigma Aldrich Chemie GmbH (Taufkirchen, Germany). Deionized HPLC water was produced by using Simplicity 185 purification system, Millipore (Billerica, USA). $\mathrm{pH}$ of the aqueous part of the mobile phase was adjusted by adding an appropriate amount of formic or acetic acid Sigma Aldrich Chemie GmbH (Taufkirchen, Germany). 


\section{Instruments and chromatographic conditions}

Experiments were performed on Dionex Ultimate 3000 (Thermo Fisher Scientific, USA) equipped with a Photodiode array detector (PDA). Analyte's separation was achieved on monolithic C18 column Chromolith performance RP-18e (100 x $4.6 \mathrm{~mm}$, $2 \mu \mathrm{m}$ macropore size, $13 \mathrm{~nm}$ mesopore size) (Merck, Germany) at the temperature set to $25^{\circ} \mathrm{C}$. A pH-meter with the combined electrode (PHM 210, Radiometer, Denmark) was used to adjust the $\mathrm{pH}$ of the prepared solutions. Before use, all mobile phases were filtered through membrane filter $0,45 \mu \mathrm{m}$ pore size (Agilent Technologies, Germany). Detection was performed at $285 \mathrm{~nm}$. The flow rate was set to $1 \mathrm{~mL} \mathrm{~min}^{-1}$, while the injection volume was $10 \mu \mathrm{L}$.

Aqueous mobile phases were prepared by dissolving the appropriate amount of $\beta$ $\mathrm{CD}$ in water $(5-15 \mathrm{mM})$ and adding either perchloric or trifluoroacetic acid in the appropriate percentage $(0.1-1 \%)$.

\section{Preparation of stock and working solutions}

Risperidone, olanzapine, and their impurities stock solutions were prepared by dissolving the appropriate amount of reference standard substance in the mixture of acetonitrile and water 50:50 (v/v) to obtain the concentration of $1 \mathrm{mg} \mathrm{mL}^{-1}$. Stock solutions of olanzapine and its related impurity were kept protected from sunlight due to their susceptibility to photodegradation. Working solutions were prepared by taking an appropriate volume of stock solutions and dissolving it in the mobile phase. Concentrations of risperidone and its impurity working solutions were $150 \mu \mathrm{g} \mathrm{mL}^{-1}$ and $50 \mu \mathrm{g} \mathrm{mL}{ }^{-1}$, respectively. Olanzapine and its impurity working solutions were prepared following the same procedure and in the same concentrations as in the case of risperidone and its impurity. Inclusion complexes formation in the solution was induced by mixing the working solutions on a Vortex mixer for 30 minutes prior to analyses.

\section{Experimental plan}

Experimental plan was created using Design Expert 7.0.0. software Stat-Ease, Inc. (Minneapolis, USA). Preliminary experiments were performed to define the factor ranges, while experimental space was properly covered by applying central composite design.

\section{Results and discussion}

Central composite design, as response surface type of experimental design, was used to define the experimental space and choose optimal conditions for the separation of risperidone and its impurity, as well as olanzapine and its impurity. In order to choose the factors which would be optimized through $\mathrm{CCD}$, preliminary investigations were conducted. Based on the preliminary experiments the following numerical factors were included in the experimental design: acetonitrile content $(\%, \mathrm{v} / \mathrm{v}), \beta-\mathrm{CD}$ concentration $(\mathrm{mM})$, and chaotropic ion concentration $(\%, \mathrm{v} / \mathrm{v})$. Selected factors and their corresponding domains are presented in Table I. 
Table I Investigated factors and their corresponding levels

Tabela I Ispitivani faktori i njima odgovarajući nivoi

\begin{tabular}{|c|c|c|c|}
\hline \multirow{2}{*}{ Investigated factors } & \multicolumn{3}{|c|}{ Level } \\
\cline { 2 - 4 } & -1 & 0 & +1 \\
\hline $\begin{array}{c}\text { Acetonitrile content } \\
(\%, \mathrm{v} / \mathrm{v})\end{array}$ & 15 & 20 & 25 \\
\hline $\begin{array}{c}\text { Chaotrope agent } \\
\text { content } \\
(\%, \mathrm{v} / \mathrm{v})\end{array}$ & 0.1 & 0.55 & 1 \\
\hline $\begin{array}{c}\beta-\mathrm{CD} \text { concentration } \\
(\mathrm{mM})\end{array}$ & 5 & 10 & 15 \\
\hline
\end{tabular}

Together with numeric factors, the type of chaotropic agent (trifluoroacetic or perchloric acid), was included in the design as a categorical variable. Table II (supplementary at the end of the paper) shows the obtained experimental plan as well as responses that were followed. Responses included retention factors $(k)$ and peak width of all investigated analytes, as well as resolutions between risperidone and its impurity, and olanzapine and its impurity. The relation between change in response influenced by a change in the value of the factors is characterised by a mathematical model. For each of the responses Design- Expert software suggested separate mathematical models.

Table II Experimental plan obtained by applying CCD (supplementary material)

Tabela II Plan eksperimenata dobijen primenom CCD-a (dodatni materijal)

\begin{tabular}{|c|c|c|c|c|c|c|c|c|c|c|c|c|c|c|}
\hline No. & 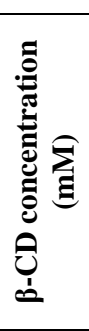 & 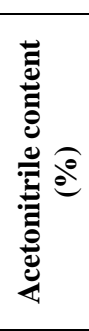 & 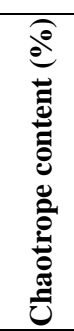 & 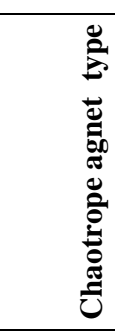 & 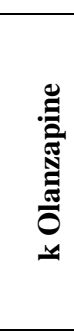 & 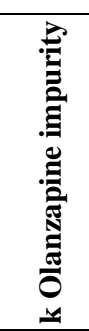 & 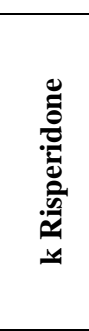 & 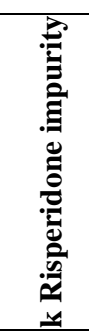 & 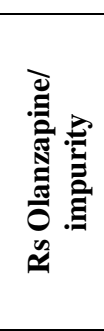 & 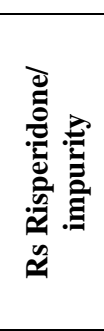 & 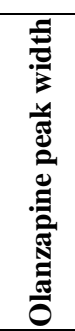 & 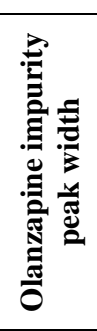 & 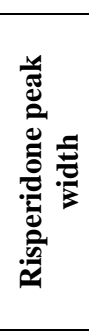 & 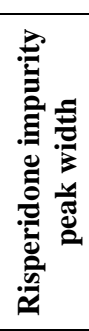 \\
\hline 1 & 5 & 15 & 0.1 & TFA & 3.04 & 4.59 & 14.57 & 10.04 & 1.38 & 2.87 & 0.54 & 0.46 & 2.27 & 1.11 \\
\hline 2 & 15 & 15 & 0.1 & TFA & 3.61 & 4.24 & 11.98 & 9.16 & 1.43 & 2.35 & 0.47 & 0.42 & 1.66 & 0.88 \\
\hline 3 & 5 & 25 & 0.1 & TFA & 1.90 & 1.99 & 3.13 & 2.49 & 0.00 & 2.89 & 0.36 & 0.12 & 0.33 & 0.23 \\
\hline 4 & 15 & 25 & 0.1 & TFA & 3.16 & 1.92 & 3.04 & 2.53 & 0.00 & 2.87 & 0.21 & 0.09 & 0.39 & 0.16 \\
\hline 5 & 5 & 15 & 1 & TFA & 6.32 & 13.02 & 39.03 & 19.73 & 2.35 & 10.24 & 0.93 & 0.99 & 2.84 & 1.79 \\
\hline 6 & 15 & 15 & 1 & TFA & 8.88 & 11.48 & 31.31 & 17.19 & 2.19 & 9.89 & 0.87 & 0.89 & 2.00 & 1.22 \\
\hline 7 & 5 & 25 & 1 & TFA & 2.47 & 2.67 & 4.58 & 3.39 & 1.07 & 5.27 & 0.18 & 0.17 & 0.40 & 0.26 \\
\hline 8 & 15 & 25 & 1 & TFA & 3.50 & 1.87 & 5.30 & 3.39 & 0.99 & 6.46 & 0.18 & 0.15 & 0.43 & 0.10 \\
\hline 9 & 5 & 20 & 0.55 & TFA & 3.51 & 3.88 & 9.68 & 5.71 & 1.25 & 5.35 & 0.30 & 0.28 & 0.62 & 0.50 \\
\hline
\end{tabular}




\begin{tabular}{|c|c|c|c|c|c|c|c|c|c|c|c|c|c|c|}
\hline No. & 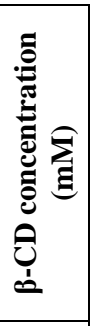 & 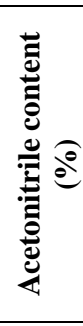 & 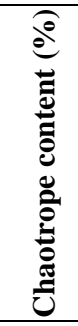 & 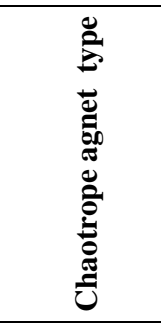 & 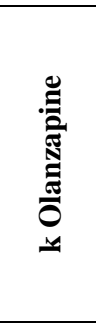 & 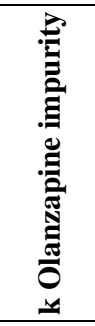 & 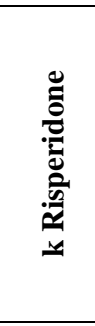 & 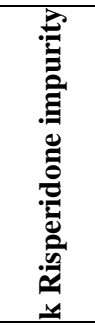 & 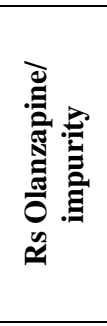 & 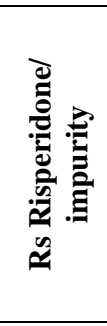 & 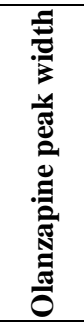 & 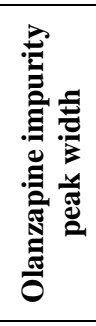 & 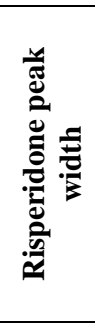 & 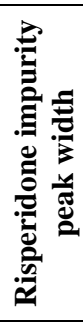 \\
\hline 10 & 15 & 20 & 0.55 & TFA & 7.99 & 3.95 & 9.55 & 5.85 & 1.42 & 5.97 & 0.29 & 0.29 & 0.76 & 0.42 \\
\hline 11 & 10 & 15 & 0.55 & TFA & 2.20 & 9.57 & 24.96 & 15.37 & 2.26 & 5.33 & 0.66 & 0.68 & 2.30 & 1.16 \\
\hline 12 & 10 & 25 & 0.55 & TFA & 2.02 & 2.32 & 3.97 & 2.83 & 0.88 & 3.84 & 0.13 & 0.12 & 0.35 & 0.21 \\
\hline 13 & 10 & 20 & 0.1 & TFA & 3.84 & 2.33 & 5.33 & 4.04 & 0.88 & 2.43 & 0.17 & 0.17 & 0.74 & 0.37 \\
\hline 14 & 10 & 20 & 1 & TFA & 4.36 & 4.36 & 10.91 & 6.24 & 1.57 & 6.60 & 0.32 & 0.32 & 0.90 & 0.46 \\
\hline 15 & 10 & 20 & 0.55 & TFA & 3.07 & 2.99 & 7.65 & 4.89 & 1.27 & 5.34 & 0.14 & 0.24 & 0.75 & 0.39 \\
\hline 16 & 10 & 20 & 0.55 & TFA & 2.65 & 4.01 & 8.32 & 5.09 & 1.45 & 5.12 & 0.35 & 0.27 & 0.68 & 0.38 \\
\hline 17 & 10 & 20 & 0.55 & TFA & 3.05 & 3.78 & 6.87 & 5.58 & 1.02 & 4.25 & 0.32 & 0.22 & 0.77 & 0.41 \\
\hline 18 & 10 & 20 & 0.55 & TFA & 3.45 & 3.56 & 7.20 & 5.25 & 1.14 & 4.65 & 0.19 & 0.26 & 0.66 & 0.29 \\
\hline 19 & 10 & 20 & 0.55 & TFA & 3.03 & 3.01 & 7.80 & 4.90 & 1.38 & 4.57 & 0.23 & 0.25 & 0.70 & 0.42 \\
\hline 20 & 10 & 20 & 0.55 & TFA & 2.54 & 3.35 & 8.10 & 4.86 & 1.28 & 4.95 & 0.25 & 0.24 & 0.78 & 0.35 \\
\hline 21 & 5 & 15 & 0.1 & Perchlorate & 5.40 & 6.37 & 24.00 & 15.27 & 1.42 & 3.00 & 0.72 & 0.57 & 2.78 & 1.41 \\
\hline 22 & 15 & 15 & 0.1 & Perchlorate & 5.38 & 6.37 & 20.22 & 16.79 & 1.90 & 2.90 & 0.72 & 0.61 & 2.11 & 1.51 \\
\hline 23 & 5 & 25 & 0.1 & Perchlorate & 3.59 & 2.45 & 6.05 & 3.57 & 0.50 & 3.39 & 0.17 & 0.17 & 1.12 & 0.36 \\
\hline 24 & 15 & 25 & 0.1 & Perchlorate & 6.06 & 2.14 & 5.89 & 4.65 & 1.20 & 3.65 & 0.14 & 0.14 & 6.22 & 0.24 \\
\hline 25 & 5 & 15 & 1 & Perchlorate & 12.46 & 20.29 & 75.00 & 34.47 & 1.98 & 6.76 & 1.45 & 1.56 & 1.65 & 3.13 \\
\hline 26 & 15 & 15 & 1 & Perchlorate & 15.67 & 20.52 & 70.00 & 33.09 & 2.57 & 8.90 & 1.17 & 1.40 & 0.99 & 2.43 \\
\hline 27 & 5 & 25 & 1 & Perchlorate & 3.92 & 4.03 & 10.23 & 5.54 & 0.74 & 4.06 & 0.31 & 0.36 & 0.89 & 0.79 \\
\hline 28 & 15 & 25 & 1 & Perchlorate & 6.19 & 3.10 & 12.26 & 6.35 & 1.35 & 6.56 & 0.28 & 0.24 & 1.92 & 0.39 \\
\hline 29 & 5 & 20 & 0.55 & Perchlorate & 6.05 & 6.94 & 19.90 & 10.64 & 1.52 & 5.90 & 0.48 & 0.42 & 1.40 & 0.68 \\
\hline 30 & 15 & 20 & 0.55 & Perchlorate & 11.95 & 6.81 & 18.54 & 10.50 & 1.81 & 7.89 & 0.44 & 0.39 & 3.78 & 0.66 \\
\hline 31 & 10 & 15 & 0.55 & Perchlorate & 3.01 & 13.90 & 48.79 & 26.72 & 2.54 & 4.91 & 1.44 & 0.88 & 1.20 & 3.41 \\
\hline 32 & 10 & 25 & 0.55 & Perchlorate & 3.09 & 4.07 & 8.50 & 5.20 & 1.40 & 5.59 & 0.25 & 0.22 & 1.28 & 0.31 \\
\hline 33 & 10 & 20 & 0.1 & Perchlorate & 7.12 & 3.38 & 8.78 & 5.88 & 1.01 & 2.97 & 0.31 & 0.24 & 3.15 & 0.59 \\
\hline 34 & 10 & 20 & 1 & Perchlorate & 6.59 & 8.03 & 22.25 & 11.82 & 1.23 & 5.26 & 0.75 & 0.53 & 1.87 & 1.23 \\
\hline 35 & 10 & 20 & 0.55 & Perchlorate & 5.12 & 6.90 & 16.44 & 9.36 & 1.75 & 4.55 & 0.47 & 0.43 & 1.86 & 1.07 \\
\hline 36 & 10 & 20 & 0.55 & Perchlorate & 6.02 & 6.90 & 16.35 & 9.42 & 1.76 & 4.55 & 0.47 & 0.43 & 1.91 & 1.37 \\
\hline 37 & 10 & 20 & 0.55 & Perchlorate & 6.54 & 6.95 & 16.39 & 9.32 & 1.75 & 4.57 & 0.47 & 0.43 & 1.72 & 0.78 \\
\hline 38 & 10 & 20 & 0.55 & Perchlorate & 6.36 & 6.76 & 16.50 & 9.30 & 1.76 & 4.57 & 0.47 & 0.43 & 1.80 & 1.25 \\
\hline 39 & 10 & 20 & 0.55 & Perchlorate & 5.46 & 6.92 & 16.50 & 9.50 & 1.78 & 4.55 & 0.47 & 0.43 & 1.85 & 0.89 \\
\hline 40 & 10 & 20 & 0.55 & Perchlorate & 6.24 & 6.90 & 16.47 & 9.35 & 1.75 & 4.58 & 0.47 & 0.43 & 1.80 & 1.08 \\
\hline
\end{tabular}

k - retention factor; Rs - resolution factor; TFA - trifluoroacetic acidHaotropni efekat trifluorosirćetne i perhlorne kiseline na formiranje inkluzionih kompleksa između $\beta$-ciklodekstrina i risperidona, olanzapina i njihovih srodnih supstanci 


\section{Olanzapine and its related impurity}

The responses analyzed in the case of olanzapine and its related impurity were their retention factors, resolution and peak widths. The dependence of each of the investigated responses upon investigated parameters was defined through mathematical models suggested by Design-Expert software. Mathematical models' equations together with values of coefficient of determination $\left(R^{2}\right.$, adjusted $R^{2}$, predicted $R^{2}$ ) for each of the investigated responses are presented in Table III. Adequacy and validity of each of the obtained models were confirmed through non-significant Lack of Fit test and high values of coefficient of determination. The retention factor of olanzapine $(k)$ needed to be transformed to inverse square root.

When analyzing the obtained equation (Table III), it could be seen that the most influential factors are the type of chaotropic agent, acetonitrile content, $\beta-\mathrm{CD}$, and chaotropic agent concentration, respectively. Taking into account the response transformation, acetonitrile content is actually negatively correlated to the olanzapine retention factor. Retention factor is reduced with an increase in values of acetonitrile content in the mobile phase, which was expected in line with the lipophilic nature of olanzapine. However, the increase in $\beta$-CD concentration would lead to retention time prolongation, which is the opposite to the postulate that the addition of $\beta-\mathrm{CD}$ in the mobile phase causes retention reduction $(8,12)$. When discussing the type of chaotropic agent and its content, they were both positively correlated to $k$. Figure 2 shows the interaction between acetonitrile and a chaotropic agent concentration, namely the expected retention prolongation with an increase in chaotropic agent concentration is not observed if acetonitrile content is high. Although the effect of acetonitrile and chaotrope on retention are opposed, with higher acetonitrile percentages, chaotropic mechanisms became negligible.

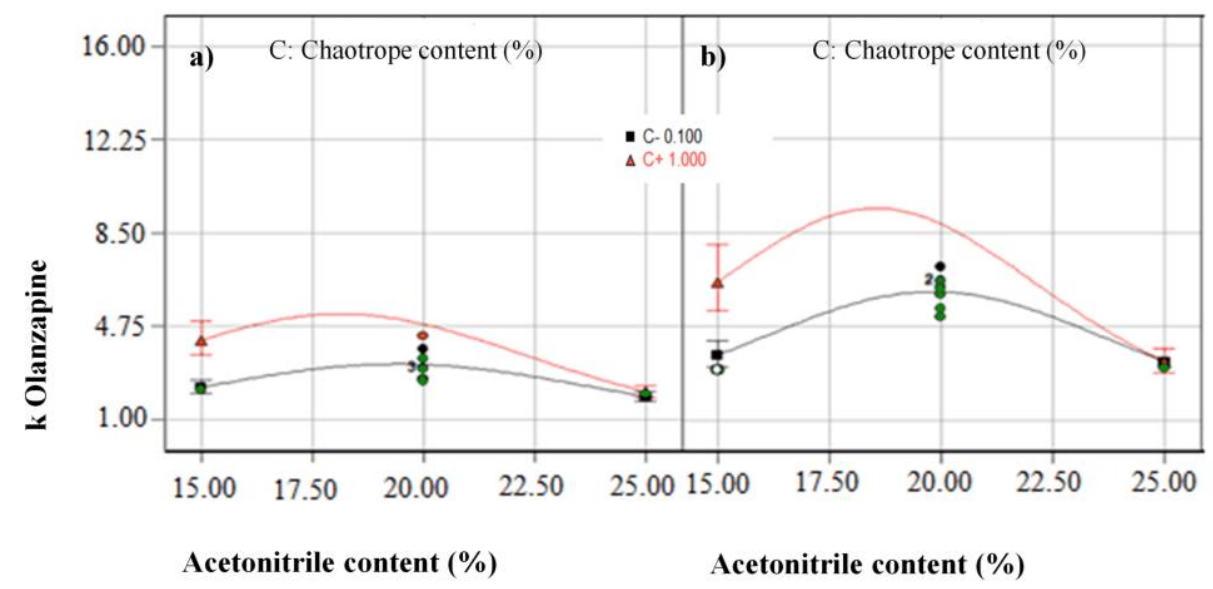

Figure 2. Olanzapine retention factor dependence on chaotrope and acetonitrile content, if trifluoroacetic acid (a) or perchloric acid (b) is used as chaotropic agent

Slika 2. Zavisnost retencionog faktora olanzapina od koncentracije haotropa $i$ acetonitrila kada su trifluorosirćetna kiselina (a) i perhlorna kiselina (b) korišćene kao haotropni agensi 
For the olanzapine impurity retention factor, Design Expert also proposed a quadratic model, with square root response transformation (Table III).

Olanzapine impurity retention factor is mostly influenced by acetonitrile content, followed by chaotropic agent concentration, type of chaotropic agent and $\beta-C D$ concentration at last. Both acetonitrile content, and $\beta-\mathrm{CD}$ concentration are showing a negative effect on retention factor, although the effect of acetonitrile is more prominent. On the other hand, as expected the type of chaotropic agent and the increase in its concentration are prolonging the retention.

Quadratic models were also suggested when analysing Rs of the critical pair denoted as olanzapine and its related impurity (Table III).

Rs between olanzapine and its impurity is the most influenced by acetonitrile content, followed by chaotropic agent concentration, the type of chaotropic agent, and finally $\beta-C D$ concentration. Among all factors, only acetonitrile content showed a negative influence on Rs. The positive effect of type and content of chaotropic agent on Rs is related to their influence on solute distribution equilibrium and reduced peak tailing, which contributes to better baseline separation. The aforementioned effect is more pronounced when the chaotropic agent concentration is higher and if the chaotropic ion from the right-hand side of the Hofmeister series, with greater ability to disrupt a water solution shell, is used. When analyzing the interactions, the most profound effect is of the interaction between the type of chaotropic agent and $\beta-\mathrm{CD}$ concentration, followed by interaction between the type and content of the chaotropic agent.

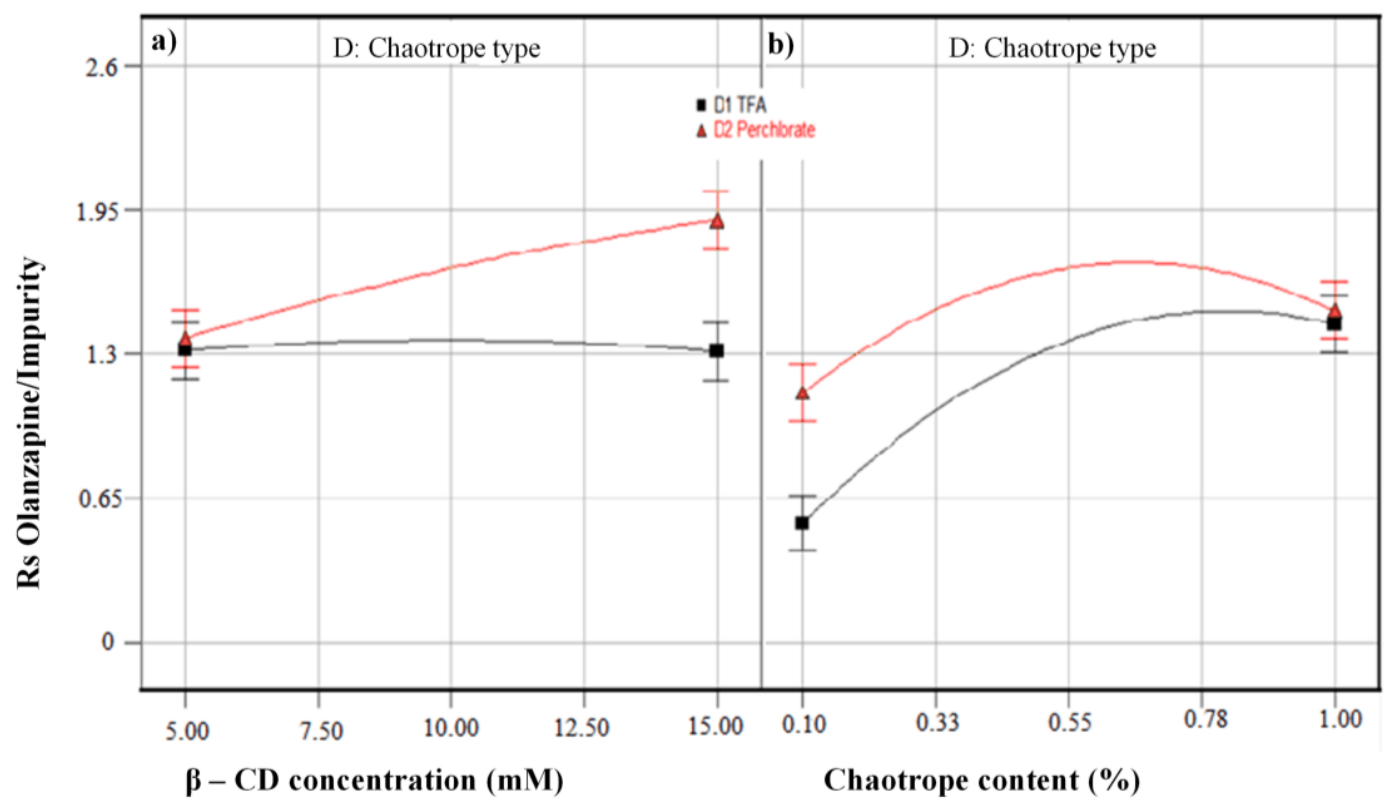

Figure 3. Rs Olanzapine/Impurity dependence on the type of chaotropic agent and $\beta$-CD concentration (a) and the type of chaotropic agent and content (b)

Slika 3. Rs Olanzapin/srodna supstanca zavisnost od tipa haotropnog agensa i $\beta$-CD koncentracije (a) i vrste i koncentracije haotropnog agensa (b) 
The first interaction shows positive, while the second one shows a negative effect on resolution. If the $\beta-C D$ concentration is at its higher factor level $(+1)$ resolution factor would increase if perchloric acid is chosen over trifluoroacetic acid (Figure 3a). On the other hand, if the chaotropic agent content is at its higher level $(+1)$, the resolution factor value would be the same, regardless of the type of chaotropic agent (Figure 3b). Rs would also be affected by the interaction between acetonitrile content and the type of chaotropic agent. It is known from the literature that the choice of organic modifier and its content would influence both eluent strength and stationary phase surface microenvironment. In that sense, the adsorption of the chaotropic agent would also be affected. Acetonitrile tends to form a thick layer on the stationary phase surface (13). Consequently, the adsorption of chaotropes is favoured until the point at which further increase in acetonitrile content would lead to shorter retention times due to the high elution capacity of the mobile phase. The decrease in Rs with an increase in acetonitrile content would be lower if perchloric acid is used as a chaotropic agent, instead of trifluoroacetic acid.

Further, the relations between peak width of olanzapine and its related impurity and investigated factors were interpreted by quadratic models with square root transformation of the peak width of olanzapine and logarithmic transformation of peak width of the impurity (Table III).

Table III Mathematical models characterizing the relation between change in response of olanzapine and its impurity influenced by the change in the values of the factors

Tabela III Matematički modeli koji opisuju zavisnost promene odgovora olanzapina i njemu srodne nečistoće od promena vrednosti ispitivanih faktora

\begin{tabular}{|c|c|c|c|c|}
\hline & Mathematical model & $\mathrm{R}^{2}$ & Adjusted $\mathrm{R}^{2}$ & Predicted $\mathrm{R}^{2}$ \\
\hline Olanzapine k & $\begin{array}{l}\mathbf{1} / \sqrt{\mathbf{k}} \text { Olanzapine }=+0.50-0.046 * \mathrm{~A}+0.055 * \mathrm{~B}-0.043 * \mathrm{C}- \\
0.068 * \mathrm{D}-0.022 * \mathrm{~A} * \mathrm{~B}+0.002048 * \mathrm{~A} * \mathrm{C}+0.009123 * \mathrm{~A} * \\
\mathrm{D}+0.034 * \mathrm{~B} * \mathrm{C}-0.011 * \mathrm{~B} * \mathrm{D}+0.008908 * \mathrm{C} * \mathrm{D}-0.10 * \\
\mathrm{~A}^{\wedge} 2+0.13 * \mathrm{~B}^{\wedge} 2-0.059 * \mathrm{C}^{\wedge} 2\end{array}$ & 0.926 & 0.889 & 0.821 \\
\hline $\begin{array}{l}\text { Olanzapine impurity } \\
\mathrm{k}\end{array}$ & $\begin{array}{l}{ }_{\mathbf{k}} \text { Olanzapine impurity }=+2.26-0.046 * \mathrm{~A}-0.80 * \mathrm{~B}+0.46 \\
* \mathrm{C}+0.30 * \mathrm{D}-0.023 * \mathrm{~A} * \mathrm{~B}-0.031 * \mathrm{~A} * \mathrm{C}+0.012 * \mathrm{~A} * \mathrm{D}- \\
0.36 * \mathrm{~B} * \mathrm{C}-0.10 * \mathrm{~B} * \mathrm{D}+0.11 * \mathrm{C} * \mathrm{D}+0.018 * \mathrm{~A}^{\wedge} 2+0.31 * \\
\mathrm{~B}^{\wedge} 2-0.21 * \mathrm{C}^{\wedge} 2\end{array}$ & 0.986 & 0.979 & 0.962 \\
\hline $\begin{array}{c}\text { Rs } \\
\text { Olanzapine/Impurity }\end{array}$ & $\begin{array}{l}\text { Rs olanzapine/impurity }=+1.52+0.13 * \mathrm{~A}-0.59 * \mathrm{~B}+0.32 * \\
\mathrm{C}+0.16 * \mathrm{D}+0.017 * \mathrm{~A} * \mathrm{~B}-0.017 * \mathrm{~A} * \mathrm{C}+0.13 * \mathrm{~A} * \mathrm{D}- \\
0.032 * \mathrm{~B} * \mathrm{C}+0.072 * \mathrm{~B} * \mathrm{D}-0.13 * \mathrm{C} * \mathrm{D}-0.048 * \mathrm{~A}^{\wedge} 2+0.22 \\
* \mathrm{~B}^{\wedge} 2-0.38 * \mathrm{C}^{\wedge} 2\end{array}$ & 0.951 & 0.927 & 0.878 \\
\hline $\begin{array}{l}\text { Olanzapine peak } \\
\text { width }\end{array}$ & $\begin{array}{l}\sqrt{ } \text { Olanzapine peak width }=+0.60-0.023 * \mathrm{~A}-0.23 * \mathrm{~B}+0.082 \\
* \mathrm{C}+0.076 * \mathrm{D}-0.0002054 * \mathrm{~A} * \mathrm{~B}+0.003664 * \mathrm{~A} * \mathrm{C}- \\
0.00001177 * \mathrm{~A} * \mathrm{D}-0.060 * \mathrm{~B} * \mathrm{C}-0.048 * \mathrm{~B} * \mathrm{D}+0.038 * \mathrm{C} \\
* \mathrm{D}+0.0001338 * \mathrm{~A}^{\wedge} 2+0.11 * \mathrm{~B}^{\wedge} 2-0.011 * \mathrm{C}^{\wedge} 2\end{array}$ & 0.932 & 0.899 & 0.792 \\
\hline $\begin{array}{l}\text { Olanzapine impurity } \\
\text { peak width }\end{array}$ & $\begin{array}{l}\log _{10} \text { Olanzapine impurity peak width }=-0.49-0.029 * \mathrm{~A}-0.34 \\
* \mathrm{~B}+0.15 * \mathrm{C}+0.099 * \mathrm{D}-0.021 * \mathrm{~A} * \mathrm{~B}-0.002619 * \mathrm{~A} * \mathrm{C}- \\
0.002024 * \mathrm{~A} * \mathrm{D}-0.031 * \mathrm{~B} * \mathrm{C}+0.017 * \mathrm{~B} * \mathrm{D}+0.020 * \mathrm{C} * \\
\mathrm{D}+0.035 * \mathrm{~A}^{\wedge} 2+0.046 * \mathrm{~B}^{\wedge} 2-0.035 * \mathrm{C}^{\wedge} 2\end{array}$ & 0.992 & 0.988 & 0.977 \\
\hline
\end{tabular}

A - $\beta$-CD concentration in the aqueous part of the mobile phase (mM)

$\mathrm{B}$ - acetonitrile content in the mobile phase $(\%, \mathrm{v} / \mathrm{v})$

$\mathrm{C}$ - the chaotropic agent content $(\%, \mathrm{v} / \mathrm{v})$

$\mathrm{D}$ - the type of chaotropic agent used ( $\mathrm{a}$ - trifluoroacetic, $\mathrm{b}$ - perchloric acid) 
Olanzapine and its impurity peak widths are mostly affected by acetonitrile content and the least by $\beta-C D$ concentration, while both effects are negative. Knowing that efficient separation depends on narrow and symmetric peaks, it is desirable to have the lowest peak width. The joint effect of acetonitrile and chaotropic agent concentration leads to a reduction in olanzapine peak width.

\section{Risperidone and its related impurity}

The relation between retention factor $(k)$ of risperidone and its impurity and investigated factors was explained with quadratic equations proposed by Design Expert (Table 4). Adequacy of the models was confirmed through non-significant Lack of Fit tests, while the validity was shown through high values of $\mathrm{R}^{2}$ (both adjusted and predicted). Both responses required logarithmic transformation.

Table IV Mathematical models characterizing the relation between change in response of risperidone and its impurity influenced by the change in the values of the factors

Tabela IV Matematički modeli koji opisuju zavisnost promene odgovora risperidona i njemu srodne nečistoće od promena vrednosti ispitivanih faktora

\begin{tabular}{|c|c|c|c|c|}
\hline & Mathematical model & $\mathrm{R}^{2}$ & Adjusted $\mathrm{R}^{2}$ & Predicted $\mathrm{R}^{2}$ \\
\hline Risperidone $\mathrm{k}$ & $\begin{array}{l}\log _{10} \text { k Risperidone }=+1.06-0.010 * \mathrm{~A}-0.36 * \mathrm{~B}+0.18 * \mathrm{C}+ \\
0.15 * \mathrm{D}+0.025 * \mathrm{~A} * \mathrm{~B}+0.012 * \mathrm{~A} * \mathrm{C}+0.003383 * \mathrm{~A} * \mathrm{D}- \\
0.058 * \mathrm{~B} * \mathrm{C}+0.012 * \mathrm{~B} * \mathrm{D}+0.021 * \mathrm{C} * \mathrm{D}+0.050 * \mathrm{~A}^{\wedge} 2+ \\
0.070 * \mathrm{~B}^{\wedge} 2-0.069 * \mathrm{C}^{\wedge} 2\end{array}$ & 0.995 & 0.992 & 0.988 \\
\hline $\begin{array}{l}\text { Risperidone impurity } \\
\mathrm{k}\end{array}$ & $\begin{array}{l}\log _{10} \text { k Risperidone impurity }=+0.85+0.005453 * \mathrm{~A}-0.34 * \mathrm{~B} \\
+0.11 * \mathrm{C}+0.12 * \mathrm{D}+0.016 * \mathrm{~A} * \mathrm{~B}-0.008865 * \mathrm{~A} * \mathrm{C}+0.014 \\
* \mathrm{~A} * \mathrm{D}-0.039 * \mathrm{~B} * \mathrm{C}-0.002029 * \mathrm{~B} * \mathrm{D}+0.013 * \mathrm{C} * \mathrm{D}+ \\
0.032 * \mathrm{~A}^{\wedge} 2+0.085 * \mathrm{~B}^{\wedge} 2-0.050 * \mathrm{C}^{\wedge} 2\end{array}$ & 0.995 & 0.993 & 0.989 \\
\hline $\begin{array}{c}\text { Rs } \\
\text { Risperidone/Impurity }\end{array}$ & $\begin{array}{l}\text { 1/Rs Risperidone/impurity }=+0.21-0.007669 * \mathrm{~A}+0.007183 \\
* \mathrm{~B}-0.096 * \mathrm{C}-0.005093 * \mathrm{D}-0.013 * \mathrm{~A} * \mathrm{~B}-0.014 * \mathrm{~A} * \mathrm{C}- \\
0.011 * \mathrm{~A} * \mathrm{D}+0.030 * \mathrm{~B} * \mathrm{C}-0.006724 * \mathrm{~B} * \mathrm{D}+0.023 * \mathrm{C} * \\
\mathrm{D}-0.040 * \mathrm{~A}^{\wedge} 2+0.004567 * \mathrm{~B}^{\wedge} 2+0.069 * \mathrm{C}^{\wedge} 2\end{array}$ & 0.972 & 0.958 & 0.940 \\
\hline $\begin{array}{l}\text { Risperidone peak } \\
\text { width }\end{array}$ & $\begin{array}{l}\text { 1/Risperidone peak width }=+0.97-0.094 * \mathrm{~A}+0.56 * \mathrm{~B}+ \\
0.021 * \mathrm{C}-0.44 * \mathrm{D}-0.17 * \mathrm{~A} * \mathrm{~B}+0.038 * \mathrm{~A} * \mathrm{C}-0.033 * \mathrm{~A} * \\
\mathrm{D}-0.047 * \mathrm{~B} * \mathrm{C}-0.54 * \mathrm{~B} * \mathrm{D}+0.14 * \mathrm{C} * \mathrm{D}+0.006680 * \mathrm{~A}^{\wedge} 2 \\
+0.26 * \mathrm{~B}^{\wedge} 2-0.14 * \mathrm{C}^{\wedge} 2\end{array}$ & 0.989 & 0.983 & 0.963 \\
\hline $\begin{array}{l}\text { Risperidone impurity } \\
\text { peak width }\end{array}$ & $\begin{array}{l}\log _{10} \text { Risperidone impurity peak width }=-0.20-0.074 * \mathrm{~A}- \\
0.40 * \mathrm{~B}+0.087 * \mathrm{C}+0.17 * \mathrm{D}-0.043 * \mathrm{~A} * \mathrm{~B}-0.036 * \mathrm{~A} * \mathrm{C}+ \\
0.017 * \mathrm{~A} * \mathrm{D}-0.030 * \mathrm{~B} * \mathrm{C}+0.014 * \mathrm{~B} * \mathrm{D}+0.056 * \mathrm{C} * \mathrm{D}\end{array}$ & 0.948 & 0.931 & 0.907 \\
\hline
\end{tabular}

A - $\beta$-CD concentration in the aqueous part of the mobile phase (mM)

$\mathrm{B}$ - acetonitrile content in the mobile phase $(\%, \mathrm{v} / \mathrm{v})$

$\mathrm{C}$ - the chaotropic agent content $(\%, \mathrm{v} / \mathrm{v})$

$\mathrm{D}$ - the type of chaotropic agent used ( $\mathrm{a}$ - trifluoroacetic, $\mathrm{b}$ - perchloric acid) 
Both risperidone and its related impurity $k$ are mostly influenced by acetonitrile content, chaotropic agent concentration, type of chaotropic agent, and $\beta-C D$ concentration, respectively. The nature of the influence of each of the factors is in accordance with the literature data. When discussing factors' interactions, the most significant is the one between acetonitrile and chaotropic agent contents. Another interesting interaction is the one between acetonitrile content and $\beta-\mathrm{CD}$ concentration. The interaction is worth attention because both factors separately lead to retention reduction. However, when $\beta-C D$ concentration is at its higher factorial level, the risperidone retention factor will not be lower if acetonitrile content is also at its higher factorial level.

Analyzing the quadratic model explaining the resolution between risperidone and its impurity (Rs), it can be seen that acetonitrile content is negatively correlated with Rs.

Namely, an increase in acetonitrile content will cause a decrease in Rs. On contrary, all other factors are positively correlated contributing to Rs. Among interaction terms, the interaction between $\mathrm{B}$ and $\mathrm{C}$ is distinguishing. If acetonitrile content is at its +1 level, a positive effect of chaotropic concentration on Rs will not appear. Also, the effect would differ depending on the type of chaotropic agent It would not be the same with trifluoroacetic and perchloric acid.

In the case of risperidone peak width Design Expert also suggested a quadratic model with the inverse transformation of the response (Table IV).

Risperidone peak width is mostly influenced by acetonitrile content and the least influenced by the content of the chaotropic agent. Moreover, acetonitrile and chaotropic agent concentrations are showing negative, while the type of chaotropic agent and $\beta-C D$ concentration are showing positive effects on peak width. Since one of the goals of each chromatographic analysis is obtaining narrow and symmetric peaks, the aspiration is towards minimizing the peak width.

For risperidone impurity peak width Design Expert suggested a two-factor interaction model with logarithmic transformation of the response (Table IV).

Peak width is mostly influenced by acetonitrile content, while least influenced by $\beta$-CD concentration, although the increase in both factors induces peak narrowing. Among the interaction terms, the interaction between the type of chaotropic agent and concentration is distinguishing.

\section{Derringer's desirability function}

The aforementioned mathematical models for each of the investigated responses could serve for 3D-contour plots creation. Overlapping 3D-contour plots to search for optimal separation conditions, when a substantial number of responses is analyzed, is very difficult. Moreover, it almost always leads to optimal separation conditions chosen as a compromise of many solutions (14). For that reason, to search for optimal separation conditions for the presented critical peak pairs, a multicriteria decision-making approach 
was employed. Within this approach, optimal separation conditions were selected with an aid of Derringer's desirability function.

According to the desirability scale, optimal ranges for each of the investigated responses were defined. For all analytes, the criteria for retention factor was in the range of 1 to 10. Desirable values of resolution factor were above 2, which would ensure the baseline separation, even if peaks are not of the same size, which is the case when separating active compound and impurity (1). The peak width of olanzapine and its related impurity was in the domain of obtained experimental results, while peaks of risperidone and its related impurity were set to be the narrower possible.

Desirability function has value 1 when all defined goals are reached. In order to visualize the optimal regions, the 3D plot of the global desirability function was constructed. Analyzing global desirability function of olanzapine and its impurity against acetonitrile content and $\beta-\mathrm{CD}$ concentration, the following conditions for separation are selected: acetonitrile content $16 \%(\mathrm{v} / \mathrm{v})$, trifluoroacetic acid as chaotropic agent type with $0.95 \%(\mathrm{v} / \mathrm{v})$ content, and $9 \mathrm{mM} \beta-\mathrm{CD}$ concentration (Figure 4).

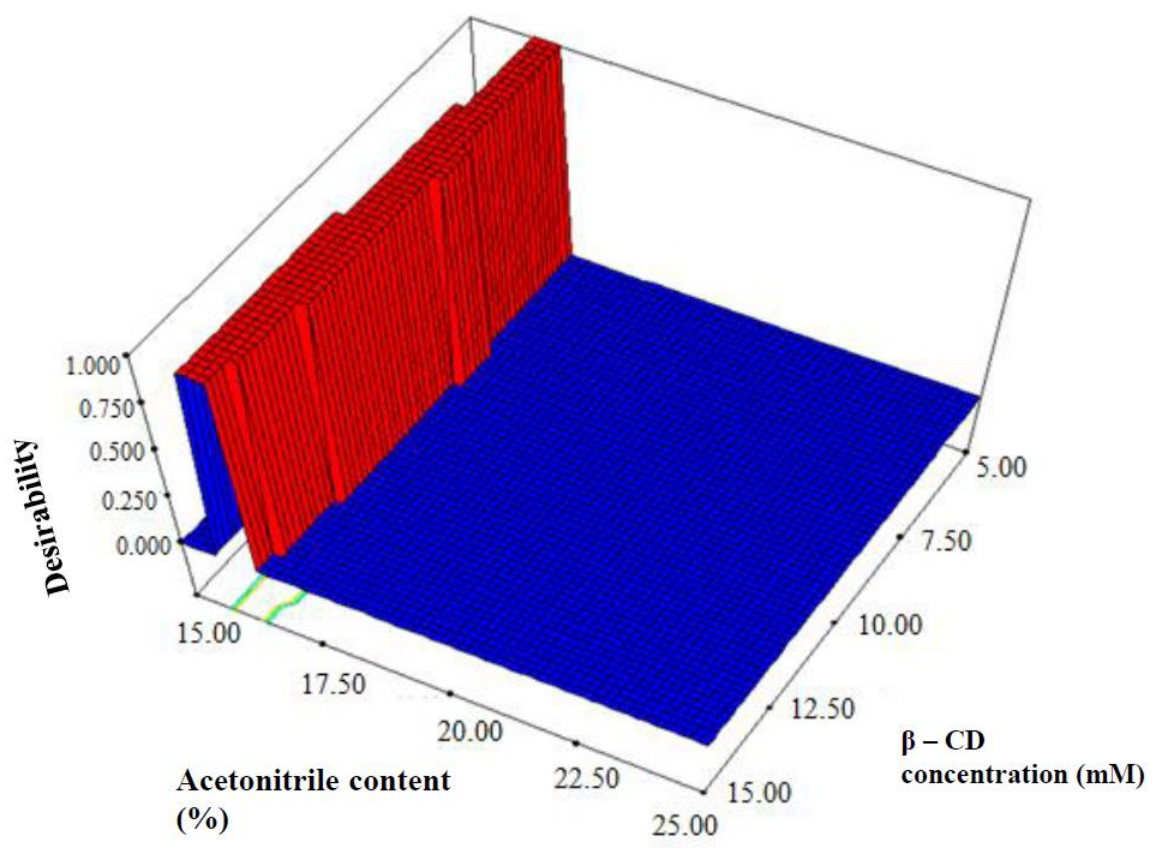

Figure 4. 3D plot of global desirability function of olanzapine and its impurity against acetonitrile content and $\beta-C D$ concentration in the mobile phase

Slika 4. 3D dijagram globalne funkcije poželjnih odgovora za olanzapin i njenu srodnu supstancu u odnosu na sadržaj acetonitrila i koncentraciju $\beta$-CD u mobilnoj fazi 
3D plot of global desirability function against acetonitrile content and $\beta-C D$ concentration was also created for risperidone and its related impurity (Figure 5).

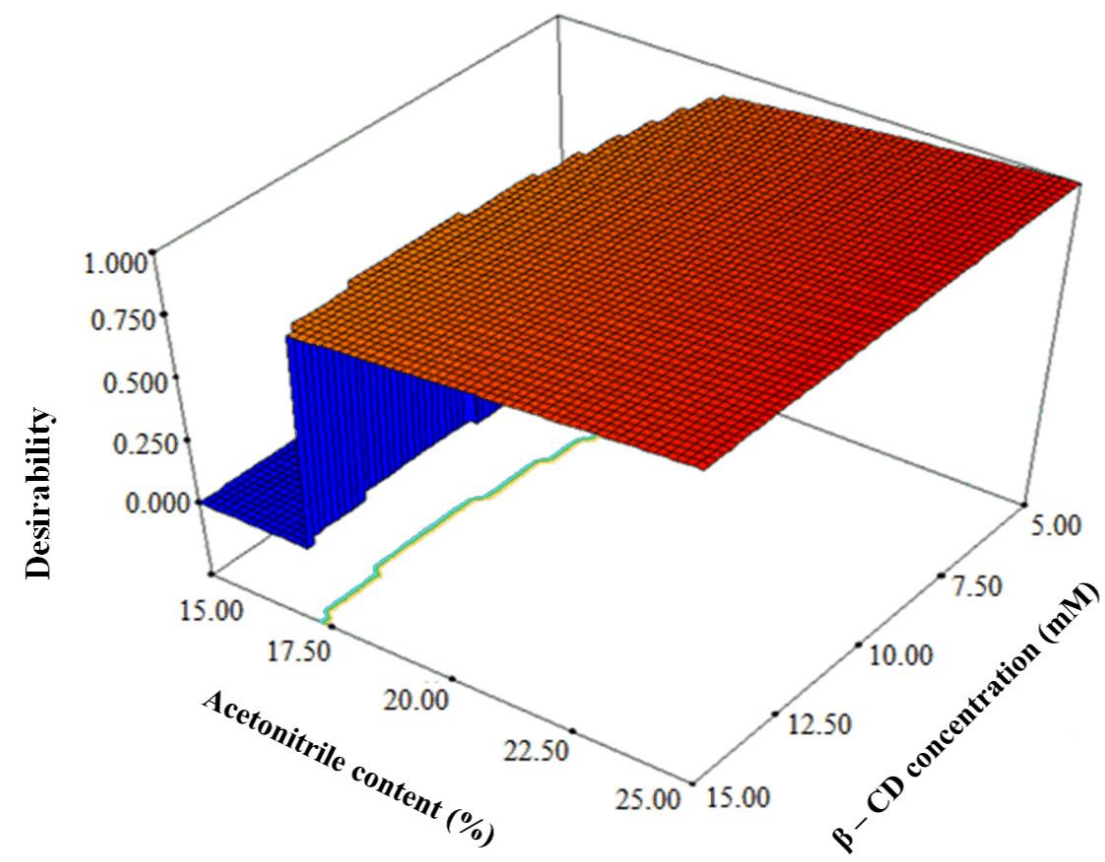

Figure 5. 3D plot of global desirability function of risperidone and its impurity against acetonitrile content and $\beta$-CD concentration in the mobile phase

Slika 5. 3D dijagram globalne funkcije poželjnih odgovora za risperidon i njegovu srodnu supstancu u odnosu na sadržaj acetonitrila i koncentraciju $\beta$-CD u mobilnoj fazi

Conditions leading to the achievement of all defined response goals are as follows: acetonitrile content $25 \%(\mathrm{v} / \mathrm{v})$, trifluoroacetic acid as the type of chaotropic agent with $0.27 \%(\mathrm{v} / \mathrm{v}$ ) concentration, and $5 \mathrm{mM} \beta-\mathrm{CD}$ concentration. In the case of both critical peak pairs, the achievement of defined response goals depends mostly on the acetonitrile content in the mobile phase. On the other hand influence of $\beta$-CD concentration was much lower in comparison to the acetonitrile effect. Chromatograms obtained under optimal separation conditions for risperidone and its impurity on one hand and olanzapine and its impurity on the other hand are shown in Figure 6. 

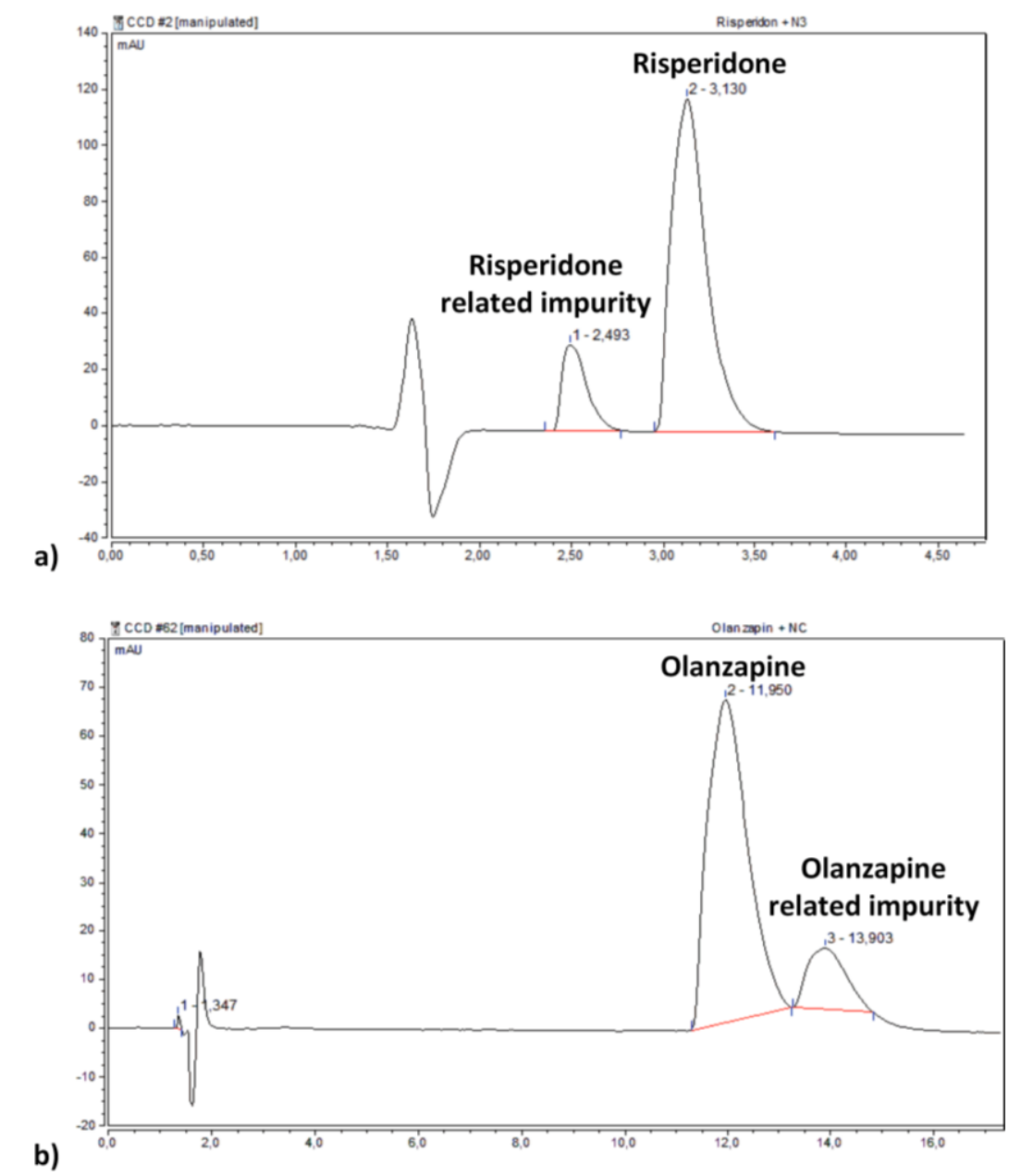

Figure 6. Representative chromatograms obtained under defined optimal chromatographic conditions for (a) risperidone and its related impurity and (b) olanzapine and its related impurity

Slika 6. Reprezentativni hromatogram dobijen pod definisanim optimalnim hromatografskim uslovima za (a) risperidon i njegovu srodnu supstancu i (b) olanzapin i njegovu srodnu supstancu

\section{Conclusion}

CD-modified RP-HPLC systems generally show a greater level of complexity in comparison to regular RP-HPLC systems, due to multiple interactions that can occur between solute and mobile and stationary phase components. Moreover, the chaotropic agent is included in the mobile phase simultaneously contributing to the overall system's complexity. As expected, acetonitrile and chaotropic agents are showing inverse effects on retention factors. Also, if acetonitrile content in the mobile phase is high, the effect of the chaotropic agent becomes negligible. Interactions that investigated analytes are forming with either chaotropic agent or acetonitrile outperformed their interactions with 
$\beta$-CD. Therefore, complexation based retention reduction is not fully exposed. Nevertheless, the reason to introduce chaotropic agents in this kind of chromatographic system was to disrupt the solvation shell around both the solute and $\beta-\mathrm{CD}$, which could contribute to the efficiency of complexation. Optimal separation conditions were obtained via desirability function and for olanzapine and its impurity they included the following: acetonitrile content $16 \%(\mathrm{v} / \mathrm{v})$, trifluoroacetic acid as the type of chaotropic agent with $0.95 \%(\mathrm{v} / \mathrm{v})$ content, and $9 \mathrm{mM} \beta-\mathrm{CD}$ concentration. Further, optimal separation conditions for risperidone and its impurity were $25 \%(\mathrm{v} / \mathrm{v})$ acetonitrile content in the mobile phase, trifluoroacetic acid as the type of chaotropic agent with $0.27 \%(\mathrm{v} / \mathrm{v})$ content, and $5 \mathrm{mM} \beta-\mathrm{CD}$ concentration.

\section{References}

1. Snyder LR, Kirkland JJ, Dolan JW. Introduction to modern liquid chromatography: John Wiley \& Sons; 2011.

2. Kazakevich Y, LoBrutto R, Vivilecchia R. Reversed-phase high-performance liquid chromatography behavior of chaotropic counteranions. Journal of Chromatography A. 2005;1064(1):9-18.

3. Flieger J, Świeboda R. Application of chaotropic effect in reversed-phase liquid chromatography of structurally related phenothiazine and thioxanthene derivatives. Journal of Chromatography A. 2008;1192(2):218-24.

4. Vemić A, Stojanović BJ, Stamenković I, Malenović A. Chaotropic agents in liquid chromatographic method development for the simultaneous analysis of levodopa, carbidopa, entacapone and their impurities. Journal of pharmaceutical and biomedical analysis. 2013;77:9-15.

5. Pan L, LoBrutto R, Kazakevich YV, Thompson R. Influence of inorganic mobile phase additives on the retention, efficiency and peak symmetry of protonated basic compounds in reversed-phase liquid chromatography. Journal of Chromatography A. 2004;1049(1-2):63-73.

6. Mura P. Analytical techniques for characterization of cyclodextrin complexes in aqueous solution: a review. Journal of pharmaceutical and biomedical analysis. 2014;101:238-50.

7. Szente L, Szemán J, Sohajda T. Analytical characterization of cyclodextrins: History, official methods and recommended new techniques. Journal of pharmaceutical and biomedical analysis. 2016;130:347-65.

8. González-Ruiz V, León AG, Olives AI, Martin MA, Menéndez JC. Eco-friendly liquid chromatographic separations based on the use of cyclodextrins as mobile phase additives. Green Chemistry. 2011;13(1):115-26.

9. Shaaban H. New insights into liquid chromatography for more eco-friendly analysis of pharmaceuticals. Analytical and bioanalytical chemistry. 2016;408(25):6929-44.

10. Del Valle EM. Cyclodextrins and their uses: a review. Process biochemistry. 2004;39(9):1033-46.

11. Abarca RL, Rodriguez FJ, Guarda A, Galotto MJ, Bruna JE. Characterization of beta-cyclodextrin inclusion complexes containing an essential oil component. Food chemistry. 2016;196:968-75. 
12. Dodziuk H. Cyclodextrins and their complexes: chemistry, analytical methods, applications: John Wiley \& Sons; 2006.

13. Kazakevich Y, LoBrutto R, Chan F, Patel T. Interpretation of the excess adsorption isotherms of organic eluent components on the surface of reversed-phase adsorbents: Effect on the analyte retention. Journal of Chromatography A. 2001;913(1-2):75-87.

14. Candioti LV, De Zan MM, Camara MS, Goicoechea HC. Experimental design and multiple response optimization. Using the desirability function in analytical methods development. Talanta. 2014;124:123-38. 


\title{
Haotropni efekat trifluorosirćetne i perhlorne kiseline na formiranje inkluzionih kompleksa između $\beta$-ciklodekstrina i risperidona, olanzapina $i$ njihovih srodnih supstanci
}

\author{
Nevena Djajić, Jovana Krmar, Andjelija Malenović, Biljana Otašević, \\ Ana Protić*
}

\begin{abstract}
Univerzitet u Beogradu - Farmaceutski fakultet, Katedra za analitiku, Vojvode Stepe 450, 11152 Beograd, Srbija
\end{abstract}

*Autor za korespondenciju: Ana Protić, E-mail: anna@pharmacy.bg.ac.rs

\section{Kratak sadržaj}

U novije vreme sve više pažnje se poklanja efikasnom razvoju metode uz istovremenu procenu njenih ekoloških karakteristika. Jedna of često primenjivanih strategija za razdvajanje baznih jonizacionih supstanci jeste dodatak haotropnih soli u mobilnu fazu. Sa druge strane, ekološki prihvatljiva metoda tečne hromatografije može se razviti dodatkom ciklodekstrini (CD) kao aditiva mobilne faze. Cilj ovog rada je bio da se istraži mogućnost dodatka haotropnih agenasa u mobilnu fazu u kojoj se već nalaze $\mathrm{CD}$. Na ovaj način moglo bi doći do narušavanja solvatacionog omotača oko analita, što bi ubrzalo proces kompleksiranja analita i CD. Model smeša se sastojala od risperidona, olanzapina i njihovih srodnih supstanci. Metoda je razvijana primenom metodologije eksperimentalnog dizajna, dok su optimalni uslovi birani primenom Deringerove funkcije poželjnih odgovora. Matematički modeli koji su dobijeni za svaki posmatrani odgovor, omogućili su da se ispita pojedinačni i zajednički uticaj koncentracije $\beta$-CD, tipa i koncentracije haotropnog agensa, kao i količine acetontrila u mobilnoj fazi. Pokazalo se da najveći uticaj na retencioni faktor ima količina acetonitrila u mobilnoj fazi. Povećanje koncentracije haotropa dovodi do produženja retencionog faktora, ali ukoliko je količina acetonitrila u mobilnoj fazi visoka efekat haotropa postaje zanemarljiv. Interakcija između analita i $\beta$-CD su slabe u poređenju sa interakcijama koje analit ostvaruje sa haotropnim agensom ili acetonitrilom, te proces kompleksiranja biva prevaziđen drugim vrstama interakcija u ovom komplikovanom sistemu. Iz tog razloga smanjenje retencionog vremena kao posledica kompleksiranja ne dolazi do izražaja. Uočeno je i da povećanje koncentracije $\beta$-CD dovodila je do povećanja rezolucije kritičnih parova. Optimalni hromatografski uslovi odabrani su na osnovu 3D grafikona Deringerove funkcije poželjnih odgovora. Za razdvajanje olanzapina i njegove srodne supstance, optimalni uslovi su obuhvatali $16 \%$ acetonitrila, $0,95 \%$ trifluorosirćetnu kiselinu kao haotropni agens i $9 \mathrm{mM} \beta$-CD. Optimalni uslovi u slučaju razdvajanja risperidona i njegove srodne supstance obuhvatali su $25 \%$ acetonitrila, $0,27 \%$ trifluorosirćetne kiseline i $5 \mathrm{mM}$ $\beta-\mathrm{CD}$.

Ključne reči: risperidon; olanzapin; haotropni agensi; $\beta$-CD;

Deringerova funkcija poželjnih odgovora 